Araş̦tırma Makalesi

\title{
Bireylerin COVID-19 Sürecinde Fiziksel Aktivite Düzeylerindeki Değişimin İncelenmesi
}

\author{
Hüseyin ÜNLÜ ${ }^{1} \quad$ Barışcan ÖZTÜRK ${ }^{2} \quad$ Özgür AKTAŞ ${ }^{3} \quad$ Bilgihan BÜYÜKTAŞ $^{4}$
}

\begin{abstract}
$\ddot{\mathbf{O} z}$
Bu çalışma; bireylerin COVID-19 pandemi öncesinde ve pandemi sırasındaki fiziksel aktivite durumlarını karşılaştırmak amacıyla yapılmıştır. Araştırmanın örneklem grubunu Türkiye'nin farklı şehirlerinde yaşayan, 18 yaşından büyük olan ve vücut kitle indeks ortalamaları 22,86 $\pm 3,69$ olan 413 kadın, 457 erkek toplamda 870 birey oluş̧urmaktadır. Araştırmada bireylerin fiziksel aktivite durumlarını tespit etmek amacıyla ''Uluslararası Fiziksel Aktivite Anketi" (IPAQ) kullanılmıştır. Bireylerin anket sonuçlarını cinsiyet, pandemi öncesi ve pandemi sırası değişkenleriyle karşılaştırmak için SPSS istatistik paket programı kullanılmışıtır. KolmogorovSmirnov test sonuçlarına göre verilerin normal dağılmadığı tespit edilmiş ve nonparametrik testlerden olan Mann Whitney U ve Wilcoxon testleri kullanılmıştır. Bu çalışmada anlamlılık düzeyi $(p)<0.05$ olarak kabul edilmiştir. Elde edilen sonuçlara göre, bireylerin pandemi öncesi ve sırasındaki fiziksel aktivite toplam ve alt parametreleri arasında anlamlı bir farklılık bulunmuştur $(\mathrm{p}<0.05)$. Cinsiyete göre pandemi öncesi fiziksel aktivite düzeyleri erkek bireyler lehine anlamlı bulunurken $(p<0.05)$, pandemi sırasında cinsiyete göre anlamlı bir farklı1ık bulunamamıştır $(\mathrm{p}>0.05)$. Sonuç olarak bireylerin pandemi sırasında pandemi öncesine göre fiziksel aktivite düzeylerinde anlamlı bir şekilde düşüs tespit edilmiştir.
\end{abstract}

Anahtar Kelimeler: COVID-19, Egzersiz, Fiziksel aktivite, Toplum sağlı̆̆1

\section{Investigation of Change in Physical Activity Levels of Individuals during COVID-19 Process}

\begin{abstract}
This study was conducted to compare individuals' physical activity status prior to and during the COVID-19 pandemic. The sample group of the study consisted of 413 women and 457 men living in different cities of Turkey, over the age of 18 , with body mass index averages of $22.86 \pm 3.69$, and a total of 870 individuals. In the research, the 'International Physical Activity Questionnaire' was used to determine the physical activities of individuals. SPSS statistical package program was used to compare the survey results of individuals gender, before pandemic and during pandemic with their variables. According to the Kolmogorov-Smirnov test results, the data was not normally distributed and the Mann Whitney U and Wilcoxon tests, which are nonparametric tests, were used. In this study, the level of significance (p) was <0.05. According to the results obtained, a significant difference was found between individuals' total and sub-parameters of physical activity before and during the pandemic $(\mathrm{p}<0.05)$. While pre-pandemic physical activity levels were found to be significant in favor of male individuals according to gender $(\mathrm{p}<0.05)$, no significant difference was found according to
\end{abstract}

\footnotetext{
${ }^{3}$ Sorumlu Yazar: Aksaray Üniversitesi, Spor Bilimleri Fakültesi, Aksaray-Türkiye, ozgur.72372@gmail.com https://orcid.org/0000-0002-3709-2813

${ }^{1}$ Aksaray Üniversitesi, Spor Bilimleri Fakültesi, Aksaray-Türkiye, unlu68@gmail.com, https://orcid.org/0000-0002$\underline{3079-4417}$

${ }^{2}$ Çukurova Üniversitesi, Spor Bilimleri Fakültesi, Adana-Türkiye, bariscan.ozturk.bc@ @mail.com, https://orcid.org/00000001-7001-3032

${ }^{4}$ Çukurova Üniversitesi, Spor Bilimleri Fakültesi, Adana-Türkiye bilgihanbykts10@ gmail.com, https://orcid.org/0000$\underline{0002-6816-7275}$
} 
gender during the pandemic $(\mathrm{p}>0.05)$. As a result, a significant decrease in the physical activity levels of individuals was detected during the pandemic compared to before the pandemic.

Keywords: COVID-19, Exercise, Physical activity, Community health.

\section{GİRIŞ}

Globalleşme kavramı ve daima ilerleme kateden teknoloji, dünyayı kolay erişilebilir bir hâle getirmiştir. Günümüzde uluslararası seyahatler ve kentleșmenin artışıyla birlikte dünyanın herhangi bir yerinde ortaya çıkan yeni veya değişime uğrayıp güç kazanarak geri gelen eski bir bulaşıcı hastalık, artık dünyadaki çok uzak mekânlara bile hızlı ve kolay bir şekilde ulaşabilmekte, tüm dünyayı etkisi altına alan salgınlara sebep olabilmektedir. $\mathrm{Bu}$ yüzden bu tip virüslerin sürekli gözetim altında tutulması ve daha yakından takip edilmesi gerekmektedir (Aksakoğlu, 2008). Çin'in Hubei eyaletinin başkenti olan Wuhanda 12 Aralı 2019 tarihinde ortaya çıkan ve o tarihten bu yana dünyada hızlı bir șekilde yayılarak bir numaralı gündem maddesi haline gelen yeni tip korona virüs (COVID-19) insanlık için büyük bir tehdit oluşturmaktadır (Ovalı, 2020). COVID-19 virüsünün bulaşabileceği yollardan birisi de hava damlacıklarıdır. Devletler bu virüsün yayılmasını engellemek amacıyla karantina uygulamasını seçmiş veya tüm vatandaşların evde kalmasını gerektiren önlemler almıştır. Bundan dolayı tüm spor ve fiziksel aktivite etkinlikleri askıya alınmış ya da iptal edilmiştir. Fiziksel aktiviteler sirasında özellikle grup aktivitelerindeki hiperventilasyon, önerilen 1,5 metrelik sosyal mesafe kurallarına uyulsa da enfeksiyon riskini arttırmaktadır. Çünkü çeşitli çevre ve hastalık koşulları altında, her boyuttaki damlacıkların 7-8 metreye kadar gidebildiği bildirilmiştir (Bourouiba, 2020). İnsan sağlığını korumak, hastalığın yayılma oranını ve hızını azaltmak amaciyla evde karantina uygulamasına gidilmiş fakat uzun süre evde kalmak; oturmak, uzanmak, oyun oynamak, televizyon izlemek, mobil cihaz kullanmak gibi sedanter davranışların arttığı, düzenli fiziksel aktivitenin azaldığ daha düşük enerji harcandığı görülmüștür (Gençalp, 2020). Karantina sürecinde egzersiz alışkanlığı olmayan toplumumuzda fiziksel inaktivite üst seviyelere doğru çıkmıştır (Caner ve diğerleri, 2020).

Fiziksel aktivite, enerji harcamas1 gerektiren ve iskelet kasları tarafindan üretilen herhangi bir vücut hareketi olarak tanımlanır (Hammami, Harrabi, Mohrr ve Krustrup, 2020). Aktif dinlenme, spor yapma, bisiklete binme, yürüyüş, oyun, dans, bahçe işleri, ev temizliği ve ağır alışveriş gibi harekete dayalı aktiviteleri kapsamaktadır (Sahu, 2020). Fiziksel aktivite, fizyolojik, morfolojik, metabolik ve psikolojik parametreleri iyileştirmesinin yanı sıra birçok kronik hastalık ve erken mortalite riskini azaltmakta ayrıca iskelet-kas sistemi sağlığını korumaya da yardımc1 olmaktadır (Heyward, 2020). Düzenli olarak yapılan egzersiz; kardiyak olaylar1 (enfarktüs, hipertansiyon), tip 2 diyabeti, kolon ve meme kanserini, obeziteyi, depresyon ve anksiyeteyi, safra kesesi hastalıklarını ve osteoporotik kırıkları azaltmaktadir (Ehrman, Gordon, Visich ve Keteyian, 2019; ACSM, 2013). Bu sebeple haftanın her günü ya da en azından birkaç gününde 30 dakika veya üzerinde orta düzeyde bir şiddetle fiziksel aktivite yapılması gerekmektedir (Savc1, Öztürk, Arıkan, İnce ve Tokgözoğlu, 2020; Driskell, Kim ve Goebel, 2020). Yetersiz fiziksel aktivite sebebiyle en bașta kilo artışları görülmekte ve buna bağlı olarak fizyolojik ve morfolojik değişimler meydana gelmektedir. Ayrica, yetersiz fiziksel aktivitenin, mortalite riskinin artmasina da sebep olduğunu gösteren çalışmalar mevcuttur (Ensrud ve diğerleri, 2014). Yapılan araştırmalar, fiziksel aktivitenin bağışıklık sisteminde bulunan faydalı hücre sayısını arttırdığını ve bu sayede bağışıklık sistemini güçlendirdiğini göstermiş ayrıca egzersiz şiddetinin inflamatuar faktörler ve bağışıklık hücreleri üzerindeki etkisinin gözden geçirildiği bir başka 
çalışmada da yüksek şiddetli egzersizin genel sağlık düzeyini geliştirdiği belirtilmiştir (Nieman ve Wentz, 2019; Arslan ve Ercan, 2020). Bu bağlamda vücudu salgına karşı

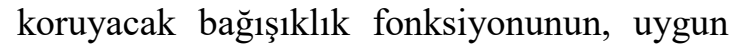
fiziksel aktivite ile artırılması önem arz etmektedir. Yapılan çalışmalar, fiziksel aktivitenin insan sağlı̆̆ını geliştirmede önemli bir faktör olduğunu göstermektedir. Dolayısıyla COVID-19 virüsüne karş1 bağışıklık sistemini güçlendirmek ve genel fiziksel kapasiteyi arttırmak amaciyla bireylerin orta yoğunlukta egzersizler yapmaları; sağlıklarını koruma ve geliştirmede hususunda, vücut direncini arttırmada fiziksel aktivitenin önemli rol oynayacağını göstermektedir (RahmatiAhmadabad ve Hosseini, 2020).

\section{Araştırmanın Amacı}

Yukarıda belirtilen bağlamlardan hareketle bu araştırma, bireylerin pandemi öncesi ve pandemi sirasındaki fiziksel aktivite düzeylerini ortaya koymak amaciyla yürütülmüştür.

\section{YÖNTEM}

Aksaray Üniversitesi Rektörlüğü/ İnsan Araştırmaları Etik Kurulu'ndan 22.06.2020 tarihinde 2020/06-88 numarali bu araştırmanın etik kurallara uygun olduğunu tescilleyen rapor alınmıştır. Helsinki etik kurallarına da uyulmuştur.

\section{Araştırma Modeli}

Betimsel çalışma; çok sayıda elemandan oluşan bir evrende, evren hakkında genel bir yargıya varmak amacı ile evrenin tümü ya da ondan alınacak bir grup üzerinde yapılan tarama düzenlemeleridir (Karasar, 2013).

\section{Örneklem}

Örneklem seçiminde gelişigüzel örnekleme yöntemi seçilmiştir. Gelişigüzel örneklem seçiminde kapsamlı bir çalışma söz konusu değildir. $\mathrm{Bu}$ nedenle sistematik bir örneklem belirleme sürecinden bahsedilemez. (Baştürk ve Taştepe, 2013).

$\mathrm{Bu}$ çalışmanın araştırma grubunu Türkiye'nin farklı şehirlerinde (Gaziantep, Adana, Kilis, İstanbul, Giresun, Amasya, Aksaray, Bursa,
İzmir, Kırıkkale, Sivas, Erzurum, Erzincan, Mersin, Antalya, Siirt) yaşayan, 18 yaşından büyük ve vücut kitle indeks ortalamalar1

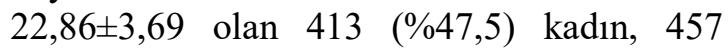
$(\% 52,5)$ erkek toplamda 870 birey oluşturmaktadır. Araştırmaya katılımda tamamen gönüllük esas alınmış ve internet ortamında hazırlanan sorulara katılımcilar çevrimiçi cevap vermiştir.

\section{Veri Toplama Araçları}

Araştırmada veri toplama aracı olarak araştırmacılar tarafından hazırlanan "kişisel bilgi formu" ve "uluslararast fiziksel aktivite anketi (IPAQ)" kullanılmıştır.

1-) Kişisel Bilgi Formu: Araştırmada katılımcılara ait yaş, cinsiyet ve vücut ağırlığı, boy uzunluğu gibi demografik özelliklerin belirlenmesi amacıyla araştırmacılar tarafından oluşturulan kişisel bilgi formu kullanılmıştır.

\section{2-) Uluslararast Fiziksel Aktivite Anketi} (IPAQ): Fiziksel aktivite, enerji harcamasıyla sonuçlanan, iskelet kaslarıyla gerçekleştirilen herhangi vücut hareketi olarak tanımlanmaktadır. Fiziksel aktivite sadece sportif faaliyetlerden (egzersiz, antrenman vb.) oluşmamakta ayrıca bireyin gün içinde yaptığı tüm aktiviteleri kapsamaktadır. Bireylerin fiziksel aktivite düzeyleri belirlenmek istendiğinde objektif ve subjektif olarak değerlendirilebilmektedir (Özer, 2013). Bireylerin fiziksel aktivite düzeylerini belirlemek amaciyla subjektif fiziksel aktivite değerlendirme yöntemlerinden Uluslararas1 Fiziksel Aktivite Anketi (IPAQ) uygulatılmıştır. Anket, 7 sorudan oluşmaktadır. Uluslararası arenada günlük olarak yapilan fiziksel aktivitenin bireysel raporlara dayanarak aktivite düzeyi hakkında geçerli ve karşılaştırılabilir bilgi elde etmek amacıyla 2003 yılında Craig ve arkadaşları tarafından geliştirilmiştir (Craig ve diğerleri, 2003). Ölçeğin Türkiye'de geçerlik ve güvenirlik çalışması 2005 yılında Öztürk tarafından yapılmıştır (Öztürk, 2005). Bu çalışmada COVID-19 pandemi öncesi ve pandemi sırasında bireylerin fiziksel aktivite düzeylerini belirleyecek şekilde IPAQ kurgulanmıştır. Anket, son 7 günde en az 10 
dakika yapılan fiziksel aktivite ile ilgili sorular içermektedir. Bireylerin ankete verdikleri yanttlar neticesinde uygulanan formül ile son haftada kaç gün ve her bir gün için ne kadar süre ile şiddetli fiziksel aktiviteler (ŞFA), orta şiddetli fiziksel aktiviteler (OFA) ve yürüme (Y) yapıldığ 1 belirlenmektedir (Tablo 1). Son soruda ise günlük olarak hareket etmeden (oturarak, yatarak vs.) harcanan zaman belirlenmektedir (Bozkuş ve diğerleri, 2013).

Uluslararası Fiziksel Aktivite Anketi (IPAQ) Uygulama Protokolü: Fiziksel aktivite düzeyini belirlemek için MET (Metabolik Eşdeğer) yöntemi kullanılmaktadır. MET=3,5 $\mathrm{ml} / \mathrm{kg} / \mathrm{dk}$. İstirahat halinde iken her kişi, bir kg başına bir dakikada $3,5 \mathrm{ml}$ oksijen tüketmektedir.

IPAQ'ta, (ŞFA=8,0 MET), (OFA=4,0 MET) ve $(Y=3,3$ MET) olarak harcandığ kabul edilmektedir. Kişinin haftada kaç gün ve ne kadar süre ile ŞFA, OFA ve Y yaptığını tespit ederek bu üç farklı fiziksel aktivitede harcanan toplam MET miktarı hesaplanmaktadır (Bozkuş ve diğerleri, 2013).

Tablo1. Örnek Hesaplama

\begin{tabular}{lllll}
\hline $\begin{array}{l}\text { FA } \\
\text { Tipi }\end{array}$ & MET & Gün/dk & Hafta/gün & Toplam \\
\hline YFA & 3.3 & 30 & 5 & 495 MET \\
OFA & 4 & 40 & 4 & 640 MET \\
ŞFA & 8 & 30 & 3 & 720 MET \\
\hline \multicolumn{2}{l}{ Toplam } & & & $\begin{array}{l}1855 \quad \text { MET } \\
\text { dakika/hafta }\end{array}$ \\
\hline
\end{tabular}

Toplam fiziksel aktivite skoruna göre katılımcıların fiziksel aktivite düzeyleri "düşük, orta ve yüksek" biçiminde sınıflandırılmıştır (Craig ve diğerleri, 2003).

Düşük düzey: 600 MET-dk/hafta altı.

Orta düzey: 600-3000 MET-dk/hafta aras1

Yüksek düzey: 3000 MET-dk/ hafta üstü.

\section{İşlem}

Araştırmaya gönüllülük esaslı katılan bireylerdem pandemi öncesindeki bir haftalık fiziksel aktivite durumlarını düşünerek birinci sıradaki (IPAQ) formu, daha sonra ise pandemi sürecindeki bir haftalık fiziksel aktivite durumlarını düşünerek ikinci sıradaki (IPAQ) formu doldurmaları istenmiştir.

\section{Verilerin Analizi}

İstatistiksel analizlerde, SPSS 22,0 paket programı kullanılmıştır. Verilerin normal dağ 11 ım gösterip göstermediğini belirlemek amaciyla Kolmogorov-Smirnov test sonuçlarına bakılmıştır. Veriler normal dağılım göstermediği için ikili grup karşılaştırmalarında non-parametrik testlerden Mann-Whitney U testi, pandemi öncesi ve pandemi sırasındaki fiziksel aktivite düzeylerindeki değişimi belirlemek amacıyla Wilcoxon testi kullanılmıştır. Sonuçlar ortalama ve standart sapma olarak verilmiş olup anlamlılık düzeyi $(\mathrm{p})<0.05$ olarak kabul edilmiştir.

\section{BULGULAR}

Tablo 2'de çalışmaya katılan kadın 413 $(\% 47,5)$ ve erkek $457(\% 52,5)$ toplamda 870 bireyin demografik verileri incelendiğinde, yaş ortalamalarının $25,90 \pm 20,69 \quad \mathrm{y} 1$, boylarının $1,71 \pm 0,05 \mathrm{~cm}$ olduğu, vücut ağırlıklarının $\quad 67,00 \pm 13,22 \quad \mathrm{~kg}$ olduğu görülmüştür. Vücut kitle indeks değerleri ortalamalarına bakıldığında, katılımcıların $22,86 \pm 3,69 \mathrm{~kg} / \mathrm{m}^{2}$ normal aralıkta oldukları görülmüştür.

Tablo 3'te kadin ve erkek bireylerin pandemi öncesi ve sırasındaki haftalık şiddetli fiziksel aktivite, orta dereceli fiziksel aktivite ve yürüme süreleri ile günlük oturma süreleri verilmiştir. Tablo incelendiğinde pandemi öncesindeki toplam fiziksel aktivite düzeyleri 3066,18 $\pm 2819,03$ (MET-dk/hf), pandemi sirasinda $\quad 1600,05 \pm 1867,42 \quad$ (MET-dk/hf) olduğu tespit edilmiştir. 
Tablo 2. Cinsiyete Göre Bireylerin Demografik Özellikleri

\begin{tabular}{lrrr}
\hline & Kadın & Erkek & Toplam \\
& $\mathrm{n}=413(\% 47,5)$ & $\mathrm{n}=457(\% 52,5)$ & $\mathrm{n}=870$ \\
& $\overline{\mathbf{X}} \pm \mathrm{SS}$ & $\overline{\mathbf{X}} \pm \mathrm{SS}$ & $\overline{\mathbf{X}} \pm \mathrm{SS}$ \\
\hline Yaş (yıl) & $25,56 \pm 27,65$ & $26,21 \pm 11,19$ & $25,90 \pm 20,69$ \\
Boy (m) & $1,66 \pm 0,01$ & $1,77 \pm 0,07$ & $1,71 \pm 0,05$ \\
Vücut Ağıllığı $(\mathrm{kg})$ & $62,23 \pm 11,67$ & $71,29 \pm 13,08$ & $67,00 \pm 13,22$ \\
Vücut Kitle İndeksi & $22,54 \pm 3,54$ & $23,40 \pm 3,76$ & $22,86 \pm 3,69$ \\
(kg/boy uzunluğu m $\left.{ }^{2}\right)$ & & & \\
\hline
\end{tabular}

Tablo 3. Cinsiyete Göre Bireylerin Pandemi Öncesi ve Pandemi Sırasındaki Fiziksel Aktivite ve Günlük Oturma Süreleri

\begin{tabular}{|c|c|c|c|c|}
\hline & & $\begin{array}{l}\text { Kadın } \\
\overline{\mathbf{X}} \pm \mathrm{SS}\end{array}$ & $\begin{array}{l}\text { Erkek } \\
\overline{\mathrm{X}} \pm \mathrm{SS}\end{array}$ & $\begin{array}{l}\text { Toplam } \\
\overline{\mathbf{X}} \pm \mathrm{SS}\end{array}$ \\
\hline \multirow{5}{*}{ 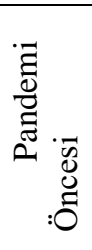 } & Şiddetli Fiziksel Aktivite (dk/hf) & $39,01 \pm 39,58$ & $62,48 \pm 50,71$ & $51,55 \pm 47,31$ \\
\hline & Orta Dereceli Fiziksel Aktivite (dk/hf) & $40,07 \pm 41,05$ & $54,34 \pm 50,50$ & $47,71 \pm 46,86$ \\
\hline & Yürüme (dk/hf) & $59,07 \pm 68,80$ & $82,31 \pm 88,78$ & $71,26 \pm 80,70$ \\
\hline & Toplam Fiziksel Aktivite (MET-dk/hf) & $2313,34 \pm 2127,34$ & $3746,54 \pm 3174,63$ & $3066,18 \pm 2819,03$ \\
\hline & Oturma (dk/gün) & $241,26 \pm 277,17$ & $272,65 \pm 246,27$ & $257,88 \pm 261,57$ \\
\hline \multirow{5}{*}{ 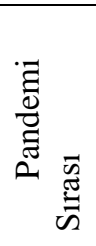 } & Şiddetli Fiziksel Aktivite (dk/hf) & $27,31 \pm 32,04$ & $35,61 \pm 38,83$ & $31,69 \pm 36,00$ \\
\hline & Orta Dereceli Fiziksel Aktivite (dk/hf) & $32,66 \pm 37,86$ & $36,66 \pm 43,96$ & $34,77 \pm 41,21$ \\
\hline & Yürüme (dk/hf) & $39,24 \pm 39,30$ & $49,66 \pm 48,98$ & $44,71 \pm 44,90$ \\
\hline & Toplam Fiziksel Aktivite (MET-dk/hf) & $1353,21 \pm 1552,66$ & $1823,14 \pm 2088,66$ & $1600,05 \pm 1867,42$ \\
\hline & Oturma (dk/gün) & $323,43 \pm 509,90$ & $357,79 \pm 480,12$ & $341,49 \pm 494,45$ \\
\hline
\end{tabular}

Tablo 4. Bireylerin Pandemi Öncesi ve Sırasındaki Fiziksel Aktivite Düzeylerinin Karşılaştırılması

\begin{tabular}{|c|c|c|c|c|}
\hline & Pandemi Öncesi & Pandemi Sıras1 & \multirow[b]{2}{*}{$\mathrm{Z}$} & \multirow[b]{2}{*}{$\mathrm{p}$} \\
\hline & $\overline{\mathrm{x}} \pm \mathrm{SS}$ & $\overline{\mathrm{x}} \pm \mathrm{SS}$ & & \\
\hline Şiddetli Fiziksel Aktivite (gün/hf) & $2,59 \pm 1,80$ & $1,98 \pm 1,75$ & $-8,05$ & $0,00^{*}$ \\
\hline Şiddetli Fiziksel Aktivite (dk/hf) & $51,55 \pm 47,31$ & $31,69 \pm 36,00$ & $-10,55$ & $0,00^{*}$ \\
\hline Şiddetli Fiziksel Aktivite (MET-dk/hf) & $1258,13 \pm 1538,71$ & $637,57 \pm 1045,04$ & $-11,97$ & $0,00^{*}$ \\
\hline Orta Dereceli Fiziksel Aktivite (gün/hf) & $2,35 \pm 1,71$ & $2,05 \pm 1,74$ & $-3,83$ & $0,00^{*}$ \\
\hline Orta Dereceli Fiziksel Aktivite (dk/hf) & $47,71 \pm 46,86$ & $34,77 \pm 41,21$ & $-8,61$ & $0,00^{*}$ \\
\hline $\begin{array}{l}\text { Orta Dereceli Fiziksel Aktivite (MET- } \\
\text { dk/hf) }\end{array}$ & $501,62 \pm 743,45$ & $351,94 \pm 562,79$ & $-7,37$ & $0,00^{*}$ \\
\hline Yürüme (gün/hf) & $5,17 \pm 2,32$ & $3,42 \pm 2,42$ & $-14,80$ & $0,00^{*}$ \\
\hline Yürüme (dk/hf) & $71,26 \pm 80,70$ & $44,71 \pm 44,90$ & $-11,15$ & $0,00^{*}$ \\
\hline Yürüme (MET-dk/hf) & $1306,42 \pm 1738,88$ & $607,09 \pm 862,79$ & $-15,51$ & $0,00^{*}$ \\
\hline Toplam Fiziksel Aktivite (MET-dk/hf) & $3066,18 \pm 2819,03$ & $1600,05 \pm 1867,42$ & $-16,34$ & $0,00^{*}$ \\
\hline
\end{tabular}

Tablo 4'te bireylerin pandemi öncesi ve sırasındaki fiziksel aktivite düzeyleri incelendiğinde şiddetli fiziksel aktivite, orta dereceli fiziksel aktivite, yürüme ve toplam fiziksel aktivite düzeyleri arasında anlamlı bir farkl111k bulunmuştur $(\mathrm{p}<0,05)$. Farkl11ı̆̆ın kaynağı incelendiğinde ise salgın sırasındaki fiziksel aktivite parametrelerinden kaynaklandığg saptanmıştır. 
Tablo 5. Kadın ve Erkek Bireylerin Pandemi Öncesi ve Sırasındaki Fiziksel Aktivite Düzeylerinin Karşılaştırılması

\begin{tabular}{|c|c|c|c|c|c|c|c|c|c|c|c|}
\hline \multicolumn{7}{|c|}{ Pandemi Öncesi } & \multicolumn{5}{|c|}{ Pandemi Siras1 } \\
\hline & & S.O & S.T & $\mathrm{U}$ & $\mathrm{Z}$ & $\mathrm{p}$ & S.O & S.T & $\mathrm{U}$ & $\mathrm{Z}$ & $\mathrm{p}$ \\
\hline \multirow{2}{*}{$\begin{array}{l}\text { Şiddetli } \\
\text { (dk/hf) }\end{array}$} & Kadın & 69,09 & 152435,0 & \multirow{2}{*}{6944,0} & \multirow{2}{*}{7,42} & \multirow{2}{*}{$0,00^{*}$} & 13,11 & 170616,0 & \multirow{2}{*}{85125,0} & \multirow{2}{*}{2,50} & \multirow{2}{*}{$0,01 *$} \\
\hline & Erkek & 495,51 & 226450,0 & & & & 455,73 & 208269,0 & & & \\
\hline \multirow{2}{*}{$\begin{array}{l}\text { Orta } \\
(\mathrm{dk} / \mathrm{hf})\end{array}$} & Kadın & 413,00 & 167152,5 & \multirow{2}{*}{1661,5} & \multirow{2}{*}{3,44} & \multirow{2}{*}{$0,00 *$} & 434,47 & 179437,0 & \multirow{2}{*}{179437,0} & \multirow{2}{*}{0,11} & \multirow{2}{*}{0,90} \\
\hline & Erkek & 457,00 & 211732,5 & & & & 436,43 & 199448,0 & & & \\
\hline \multirow{2}{*}{$\begin{array}{l}\text { Düşük } \\
\text { (dk/hf) }\end{array}$} & Kadın & 399,70 & 165077,0 & \multirow{2}{*}{9586,0} & \multirow{2}{*}{3,99} & \multirow{2}{*}{$0,00 *$} & 419,66 & 173320,0 & \multirow{2}{*}{173320,0} & - & \multirow{2}{*}{0,07} \\
\hline & Erkek & 467,85 & 213808,0 & & & & 449,81 & 205565,0 & & 1,78 & \\
\hline
\end{tabular}

*p $<0.05$; S.O: Sira Ortalamasi; S.T: Sira Toplamı

Tablo 5'te kadın ve erkek bireylerin pandemi öncesi dönemdeki fiziksel aktivite düzeyleri incelendiğinde şiddetli, orta ve düşük şiddetli fiziksel aktivite düzeylerinde anlamlı bir farkl11ı bulunmuştur $(\mathrm{p}<0.05)$. Farkl11 l̆ğın kaynağı incelendiğinde ise farklılığın tüm boyutlar için erkek bireylerden kaynaklandığ 1 saptanmıştır. Buna ek olarak kadın ve erkek bireylerin pandemi sırasındaki fiziksel aktivite düzeyleri incelendiğinde orta ve düşük şiddetli fiziksel aktivite düzeylerinde anlamlı bir farklılık bulunmazken, şiddetli fiziksel aktivite düzeylerinde anlamlı bir farkl1lık bulunmuştur $(\mathrm{p}<0.05)$. Farkl11ığın erkek bireylerden kaynaklandığı saptanmıştır.

\section{TARTIŞMA VE SONUÇ}

Dünya Sağlık Örgütü'nün (DSÖ) pandemi olarak kabul ettiği korona virüs hastalığ 1 (COVID-19) tüm dünyada olduğu gibi ülkemizde de hayatı ciddi derecede etkileyen önemli bir halk sağlığ 1 sorunu haline gelmiştir. Hastalığın yayılmasını engellemek adına alınan önlemlerle beraber insanların yaşamları çok büyük oranda değişmiştir. Alınan önlemlerden en önemlisi sosyal izolasyon olurken insanların evde kalarak bu sayede salgının yayılma hızını azaltmaları beklenmektedir. Sosyal izolasyon, salgının yayılımı konusunda önemli bir önlem olmasına rağmen insanların fiziksel aktivite durumlarını etkileyerek insan yaşamını doğrudan değiştirmiştir. Çeşitli ülkelerdeki izolasyon uygulaması fiziksel aktivite üzerindeki etkisini göstermeye başlamıştır. Nitekim Amerika'da bireylerin fiziksel aktivite düzeylerini takip etmek amaciyla giyilebilir cihazlar geliştiren bir şirketin yapmış olduğu araştırmada, 30 milyon insanı geçen y1lın aynı dönemi ile karşılaştırdıklarında ortalama fiziksel aktivite düzeylerinde önemli oranda bir azalma olduğunu tespit etmişlerdir (Ciddi ve Yazgan, 2020). Yapılan bu çalışmalar karantina ya da sosyal izolasyonun fiziksel aktivite seviyelerinde önemli bir düşüşe neden olabildiğini göstermiştir. Oysaki düzenli olarak yapılan fiziksel aktivite mortaliteye sebep olan faktörleri azaltmasının yanı sıra COVID-19 salgını sonucu oluşabilecek morbiditeler ve immünolojik faktörler üzerindeki faydaları, stresi azaltması, kısa ve uzun vadede zihinsel sağlı üzerindeki iyileştirici etkileri göz önünde bulundurulduğunda mevcut durum için oldukça önem arz etmektedir (Burtscher, Burtscher ve Millet, 2020; Burtscher ve Burtscher, 2020; Mikkelsen Stojanovska, Polenakovic, Bosevski ve Apostolopoulos, 2017; Nieman ve Wentz, 2019). Bu bağlamda bu çalışma bireylerin pandemi öncesi ve pandemi sirasındaki fiziksel aktivite düzeylerini incelemek ve alan yazına katkıda bulunmak amac1yla yürütülmüştür.

Araştırmadan elde edilen sonuçlara göre bireylerin pandemi öncesi dönemdeki fiziksel aktivite düzeyleri, pandemi sürecinde ciddi anlamda düşüş göstermiştir. Çalışmaya katılan bireylerin COVID-19 salgını öncesi süreçte toplam fiziksel aktivite düzeyleri 3066,18 $\pm 2819,03$ (MET-dk/hf) iken COVID19 salginı sirasinda $1600,05 \pm 1867,42$ (MET$\mathrm{dk} / \mathrm{hf}$ ) olduğu bulunmuştur. Akyol, Başkan ve Başkan yapmış olduğu bir çalışmada salgına 
bağl1 olarak pandemi sürecinde bireylerin fiziksel aktivite seviyelerinin düştüğünü tespit etmişlerdir (Akyol, Başkan ve Başkan, 2020). Kim ve Su (2020) COVID-19'a karş1 psikonörolojik bağışıklık üzerine yapmış oldukları bir çalışmada salgın sürecinde düzenli fiziksel aktivite ve egzersizin azaldığını saptamışlardır (Kim ve Su 2020). Benzer bir araştırmada Gençalp bireylerin fiziksel aktivite düzeylerinin yetersiz olduğunu belirtmiştir (Gençalp, 2020). Salgından dolayı alınan resmi önlemler neticesinde insanların fiziksel aktivite düzeylerinde azalmalar meydana gelmiştir. Ancak insan sağlığını korumak için alınan sosyal izolasyon önlemleri, insanları inaktiviteye ya da egzersizleri hayatlarından tamamen çıkarmaya yönlendirmemelidir (Chen ve diğerleri, 2020). Salgına bağlı olarak insanların inaktif olmaları kronik sağlı sorunlarına, vücut ağırlığı artışına, iskelet kas kütlesinin ve gücünün kaybına yol açabilir (Barazzoni, Bischoff, Krznaric, Pirlich ve Singer, 2020). Bundan dolay1 sosyal izolasyon döneminde ev ortamında uygulanabilecek güvenli, uygulanabilir ve basit egzersizlerin insanların fiziksel aktivite düzeylerini korumaya yardımc1 olacağı, bağışıklık sistemini güçlendireceği ve bu sayede korona virüse yakalanma oranlarını azaltacağı düşünülmektedir.

Çalışmaya katılan bireylerin cinsiyetlerine göre fiziksel aktivite düzeyleri incelendiğinde pandemi öncesine göre pandemi sırasında anlamlı bir şekilde düştüğü bulunmuştur. Pandemi öncesi dönemde kadınların toplam fiziksel aktivite düzeyleri 2313,34 $\pm 2127,34$ (MET-dk/hf) iken pandemi sırasında bu oran 1353,21 $\pm 1552,66 \quad$ (MET-dk/hf) seviyelere düşmüştür. Ayrıca erkeklerin toplam fiziksel aktivite düzeyleri de 3746,54 $\pm 3174,63$ (MET$\mathrm{dk} / \mathrm{hf}$ ) seviyelerinden $1823,14 \pm 2088,66$ seviyelerine kadar düşmüştür. Maugeri ve arkadaşlarının İtalya'da yaşayan bireylerin salgın öncesi ve sırasındaki fiziksel aktivite durumlarını incelediği bir çalışmada hem kadın hem de erkek bireylerin ciddi oranda fiziksel aktivite düzeylerinin azaldığını bulmuşlardır (Maugeri ve diğerleri, 2020). Lesser ve Nienhuis Kanadalı bireyler üzerinde yapmış oldukları bir çalışmada kadın ve erkek bireylerin salgın öncesi fiziksel aktivite oranlarının salgın sırasında büyük oranda düştüğünü tespit etmişlerdir (Lesser ve Nienhuis 2020). Stanton ve arkadaşları, Avusturalya'da yaşayan bireylerin fiziksel aktivite düzeylerini inceledikleri bir çalışmada ise salgın sürecinde bireylerin fiziksel aktivite oranlarının (\%48) olumsuz yönde değiştiğini bulmuşlardır (Stanton ve diğerleri, 2020). Başka bir çalışmada ise Hemphill, Kuan ve Harris, Kanada'da yaşayan ve kronik rahatsızlığ salgın süresince fiziksel aktivite düzeylerinde önemli oranda azalma olduğunu saptamışlardır (Hemphill, Kuan ve Harris, 2020). Yapılan çalışmalar ile bu çalışmadan elde edilen sonuçlar birbiriyle paralellik göstermektedir. Sosyal izolasyon, evde karantina süreci, sokağa çıkma yasağı gibi zorunlu önlemler milyonlarca insanı etkilemiş ve günlük fiziksel aktivite etkinliklerini sekteye uğratmıştır. COVID-19 pandemi sürecinde olumsuz risk faktörlerinden uzaklaşmak ve bağışıklık sistemini güçlendirmek önem arz etmektedir. Bundan dolayı bağışıklığı güçlendirmek, mevcut durumu iyileştirmek amaciyla evde yapılacak fiziksel aktivite etkinliklerinin insanların hem fiziksel hem de psikolojik yaşamlarına olumlu katkıda bulunacağı düşünülmektedir.

Sonuç olarak bu çalışmada elde edilen veriler incelendiğinde, COVID-19 salgınından dolayı resmi makamlarca alınan sosyal izolasyon önlemleri döneminde kadın ve erkek bireylerin fiziksel aktivite düzeylerinin belirgin oranda azaldığı bulunmuştur. COVID-19 salgınının insan yaşamını olumsuz yönde etkilediği, insanların hareket kabiliyet ve alanlarını sınırlandırdığı için bireylerin fiziksel aktivite düzeylerini önemli oranda azalttığı söylenebilir.

Öneriler: COVID-19 salgını, insan sağlığını her geçen gün daha da ciddi tehlikelere sürüklemektedir. $\mathrm{Bu}$ tehlikeler insanların yaşamlarına son verebilecek boyuttadır. Bireylerin bağışıklık sistemini güçlendirmek, fiziksel ve psikolojik olarak iyi oluşlarını desteklemek için fiziksel aktivitelere katılım oranlarını arttırmaları gerekmektedir. $\mathrm{Bu}$ doğrultuda resmi makamlarca ciddi ve kat1 önlemler alınarak, sosyal mesafe kuralları korunacak şekilde profesyonel sportif destek 
sağlanabilir. Tıp, beslenme, spor, fizik tedavi ve rehabilitasyon gibi bilim dallarının sarmal bir şekilde yürüteceği proje ve programlar ile insanlar fiziksel aktivite ve egzersizlere yönlendirilebilir. Fiziksel aktivitenin genel ve kardiyovasküler sağlık durumu üzerindeki olumlu etkileri göz önüne alındığında, video ve çevrimiçi rehberlik protokolleri ile yapılan egzersizler çok faydalı olabilir. Ayrıca farklı grupların (kronik rahatsızlığı bulunanbulunmayan, genç-orta ve yaşl1) fiziksel aktivite ve vücut kompozisyonlarındaki değişimler incelenebilir.

\section{KAYNAKÇA}

Aksakoğlu, G. (2008). Bulaşıcı Hastalıklarla Savaşım. İzmir: DEÜ Rektörlük Basımevi.

Akyol, G., Başkan, A. H., ve Başkan, A. H. (2020). Yeni tip koronavirüs (covid-19) döneminde spor bilimleri fakültesi öğrencilerinin karantina zamanlarında yaptıkları etkinlikler ve sedanter bireylere önerileri. Avrasya Sosyal ve Ekonomi Araştırmaları Dergisi. 7(5), 190-203.

American College of Sports Medicine. (2013). ACSM's Health-Related Physical Fitness Assessment Manual 6.ed. Lippincott Williams \&Wilkins.

Arslan, E., Ercan, S. (2020). Covid-19 pandemisi ve sosyal izolasyon sürecinde egzersizin önemi. Spor Hekimliği Dergisi. 55(2),188-191.

Barazzoni, R., Bischoff, S. C., Krznaric, Z., Pirlich, M., ve Singer, P. (2020). Espen expert statements and practical guidance for nutritional management of individuals with Sars-Cov-2 infection. Clinical Nutrition ESPEN. 39(6), 1631-1638.

Baştürk, S., ve Taştepe, M. (2013). Evren ve Örneklem: Bilimsel Araștırma Yöntemleri. Ankara: Vize Yayıncilık.

Bourouiba, L. (2020). Turbulent gas clouds and respiratory pathogen emissions: potential implications for reducing transmission of covid-19. Jama. 323(18), 18371838.
Bozkuş, T., Türkmen, M., Kul, M., Özkan, A., Öz, Ü., ve Cengiz, C. (2013). Beden eğitimi ve spor yüksekokulunda öğrenim gören öğrencilerin fiziksel aktivite düzeyleri ile sağlıklı yaşam biçimi davranışlarının belirlenmesi ve ilişkilendirilmesi. International Journal of Sport Culture and Science. 1(3), 49-65.

Burtscher, J., Burtscher, M., ve Millet G. P. (2020). (Indoor) isolation, stress and physical inactivity: vicious circles accelerated by covid-19?. Scandinavian Journal of Medicine \& Science in Sports. May 6, 10.1111/sms.13706.

Burtscher, J., ve Burtscher, M., (2020). Run for your life: tweaking the weekly physical activity volume for longevity. British Journal of Sports Medicine. 54, 759-760.

Caner, Z. G., Ünal, M., Apaydın, Z., Dağ, A., Okur, Ş., Kara, E., ve Bildik, C. (2020). Covid-19 hastalığ ve ev egzersizlerinin önemi. Journal of Medical Sciences. 1(3), 25-33.

Chen, P., Mao, L., Nassis, G. P., Harmer, P., Ainsworth, B.E., ve Li, F. (2020). Corona virus disease (covid-19): the need to maintain regular physical activity while taking precautions. Journal of Sport and Health Science. 9(2): 103-104.

Ciddi, P. K., ve Yazgan, E. (2020). Covid19 salgınında sosyal izolasyon sirasında fiziksel aktivite durumunun yaşam kalitesi üzerine etkisi. İstanbul Ticaret Üniversitesi Sosyal Bilimler Dergisi. 19(37), 262-279.

Craig, C. L., Marshall, A. L., Sjöström, M., Bauman, A. E., Booth, M. L., Ainsworth, B. E., ve Oja, P. (2003). International physical activity questionnaire: 12-country reliability and validity. Medicine \& science in sports \& exercise. 35(8), 1381-1395.

Driskell, J. A., Kim, Y. N., Goebel, K. J. (2005). Few differences found in the typical eating and physical activity habits of lower-level and upper-level university students. Journal of the American Dietetic Association. 105(5), 798-801. 
Ehrman, J. K., Gordon, P. M., Visich, P. S., Keteyian, S. J., Clinical Exercise Physiology 4th ed. USA: Human Kinetics.

Ensrud, K.E., Blackwell, T.L., Cauley, J. A., Dam, T. L. L., Cawthon, P. M., Schousboe, J. T., ve Mackey, D. C. (2014). Objective measures of activity level and mortality in older men. Journal of the American Geriatrics Society. 62(11), 2079. 2087.

Gençalp, D. K. (2020). Covid-19 salgını döneminde ilk ve acil yardım öğrencilerinin beslenme alışkanlıkları ve fiziksel aktivite durumlarının değerlendirilmesi. Paramedik ve Acil Sağllk Hizmetleri Dergisi. 1(1), 1-15.

Hammami A, Harrabi B, Mohrr B, Krustrup P. (2020). Physical activity and corona virus disease 2019 (COVID-19): Specific recommendations for home-based physical training. Managing Sport and Leisure. DOI:10.1080/23750472.2020.175 7494

Hemphill, N. M., Kuan, M. T., ve Harris, K.C. (2020). Reduced physical activity during covid-19 pandemic in children with congenital heart disease. Canadian Journal of Cardiology. 36(5), 1-5.

Heyward, V. H. (2006). Advanced Fitness Assessment and Exercise Prescription 5th ed. USA: Human Kinetics.

Karasar, N. (2013). Bilimsel Araştırma Yöntemi (11. Baskl). Ankara: Nobel Yayınevi.

Kim, S. W., ve Su, K. P. (2020). Using Psychoneuroimmunity against Covid-19. Brain, Behavior and Immunity. Jul87.

Lesser, I. A., ve Nienhuis, C. P. (2020). The impact of covid-19 on physical activity behavior and well-being

Canadians. International Journal of Environmental Research and Public Health. 17(11), 1-12.

Maugeri, G., Castrogiovanni, P., Battaglia, G., Rippi, R., D’agata, V., Palma, A., ve Musumeci, G. (2020). The impact of physical activity on psychological health during covid-19 pandemic in Italy. Heliyon. 6(6), 1-8.

Mikkelsen, K., Stojanovska, L., Polenakovic, M., Bosevski, M., ve Apostolopoulos, V. (2017). Exercise and mental health. Maturitas.106,48-56.

Nieman, D. C., Wentz, L. M. (2019). The compelling link between physical activity and the body's defense system. Journal of Sport and Health Science. 8(3), 201-217.

Ovalı, F. (2020). Yenidoğanlarda covid-19 enfeksiyonları. Anadolu Kliniğ $i$ Tip Bilimleri Dergisi. 25, 25-35.

Özer, K. (2013). Fiziksel uygunluk (4. Baskl). Ankara: Nobel Yayınevi.

Öztürk, M. (2005). Üniversitede eğitimöğretim gören öğrencilerde uluslararası fiziksel aktivite anketinin geçerliliği ve güvenirliği ve fiziksel aktivite düzeylerinin belirlenmesi. Yüksek lisans tezi, Ankara Ü. Sağlık Bilimleri Enstitüsü, Ankara.

Rahmati-Ahmadabad S., ve Hosseini F. (2020). Exercise against SARSCoV-2 (COVID-19): does workout intensity matter?(a mini review of some indirect evidence related to obesity). Obesity Medicine. 100245. https://doi.org/10.1016/j.obmed.2 020.100245

Sahu, G. S. (2020). Physical activity and covid-19. International Journal of Advance Research and Innovative Ideas in Education. 6(3), 494499.

Savcı, S., Öztürk, M., Arıkan, H., İnce, İ. D., ve Tokgözoğlu, L. (2020). Üniversite öğrencilerinin fiziksel aktivite düzeyleri. Türk Kardiyoloji Derneği Arşivi Dergisi. 34(3), 166-172.

Stanton, R., To, Q. G., Khalesi, S., Williams, S. L., Alley, S. J., Thwaite, T. L., ve Vandelanotte, C. (2020). Depression, anxiety and stress during covid-19: Associations with changes in physical activity, sleep, tobacco and alcohol use in Australian adults. International Journal of Environmental Research and Public Health. 17(11), 4065. 